\title{
Analisis Implementasi Pembelajaran Berbasis Teknologi Infromasi
}

\author{
Wahyuni Nadar \\ Pendidikan Guru Pendidikan Anak Usia Dini \\ STKIP Kusuma Negara
}

Emai: wahyuni@gmail.com

\begin{abstract}
ABSTRAK
Penelitian ini dilakukan untuk menggambarkan hasil analisis implementasi pembelajaran berbasis IT di TK Islam Bunga Bangsa Bekasi. Analisis ini mencakup pemahaman konsep pembelajaran berbasis TI yang diterapkan di TK Islam Bunga Bangsa, mengetahui hambatan dalam penerapan pembelajaran berbasis TI di TK Islam Bunga Bangsa, Bekasi dan menggambarkan strategi yang dilakukan dalam mengimplementasikan pembelajaran IT di TK Islam Bunga Bangsa. Penelitian ini dilakukan selama 3 bulan dengan pendekatan deskriptif kualitatif. Pengumpulan data dilakukan dengan wawancara, observasi dan analisis dokumen dalam bentuk dokumen kurikulum, perencanaan pembelajaran RPPH dan penilaian hasil belajar anak-anak dan dokumentasi penggunaan alat IT yang digunakan dalam pembelajaran. Analisis data dimulai dengan menggambarkan temuan-temuan penelitian dan kemudian melakukan diskusi objektif dengan pendekatan teoretis. Dalam penelitian ini proses pembelajaran dijelaskan di TK Islam Bunga Bangsa dan penggunaan alat teknologi dalam berbagai aspek komponen pembelajaran seperti media, sumber belajar dan juga sebagai dukungan pembelajaran. Proses pembelajaran lebih menarik dan tidak monoton, sehingga menciptakan suasana yang menyenangkan dan interaktif. Kendala yang ditemukan adalah masih kurangnya referensi guru untuk menggunakan perangkat TI dalam pembelajaran terkait dengan kegiatan dalam tema dan kurangnya keterampilan guru dalam menggunakan perangkat TI yang ada. Upaya saat ini untuk mengatasi kendala ini adalah dengan menyediakan berbagai referensi dalam bentuk video, buku dan lokakarya tentang penggunaan TI dalam pembelajaran.
\end{abstract}

Kata Kunci: Pembelajaran; Teknologi; Informasi

\begin{abstract}
This research was conducted to describe the results of the analysis of the implementation of IT-based learning at the Bunga Bangsa Kindergarten Islamic School Bekasi. This analysis includes understanding the concept of IT-based learning implemented at the Bunga Bangsa Islamic School Kindergarten, knowing the obstacles in the implementation of IT-based learning at the Bunga Bangsa Kindergarten Islamic School Bekasi and describing the strategies carried out in implementing IT learning at the Bunga Bangsa Islamic School Kindergarten. This research was conducted for 3 months with a qualitative descriptive approach. Data collection is done by interviews, observation and analysis of documents in the form of curriculum documents, RPPH learning planning and assessment of children's learning outcomes and documentation of the use of IT tools used in learning. Data analysis begins by describing the findings of the study and then conducts an objective discussion with a theoretical approach. In this study the learning process was described in the Bunga Bangsa Islamic School Kindergarten and the use of technological tools in various aspects of learning components such as media, learning resources and also as learning support. The learning process is more interesting and not monotonous, thus creating a fun and interactive atmosphere. The constraints found were that there was still a lack of teacher references to using IT tools in learning associated with activities in the theme and the lack of teachers' skills in using existing IT tools. Current efforts to overcome these obstacles are by providing various references in the form of videos, books and workshops on the use of IT in learning.
\end{abstract}

Key words: learning ; Technologi; Information

Pedagogika.fip@ung.ac.idＰ-ISSN : 2086-4469Ｅ-ISSN : 2716-0580 
PEDAGOGIKA

Volume 11 (Nomor 1) 2020

Hal. 1-11

(C) 2020 Wahyuni Nadar

Under The License CC-BY SA 4.0

\section{PENDAHULUAN}

Pendidikan anak usia dini bukanlah hal yang dianggap sebelah mata lagi. Saat ini pemerintah sangat berkonsentrasi dalam meningkatkan kualitas pendidikan anak usia dini di Indonesia. Hal ini terlihat dengan maraknya lembaga PAUD di kota hingga pelosok desa. Banyaknya jumlah lembaga PAUD masih belum berimbang dengan kualitas yang diharapkan untuk mencetak generasi penerus bangsa yang dapat bersaing di masa yang akan datang.

Berdasarkan data dari Kementrian Pendidikan dan Kebudayaan tahun 2017 jumlah PAUD di Indonesia yaitu 229.665 (http://referensi.data.kemdikbud.go.id/inde x21.php, 2017). 6000 lembaga diantaranya adalah milik pemerintah dan sisanya swasta.

Lembaga PAUD sebagai lembaga pendidikan yang melayani kebutuhan anak usia dini yang bertujuan unutk membentuk anak Indonesia yang berkualitas yaitu anak yang tumbuh dan berkembang sesuai dengan tingkat perkembangannya sehingga memiliki kesiapan yang optimal di dalam memasuki pendidikan dasar serta mengarungi kehidupan pada masa dewasa. Hal tersebut dipaparkan dalam Peraturan Pemerintah nomor 137 Tahun 2014 tentang Standar Nasional PAUD. Tujuan PAUD untuk jangka panjang terlihat dari kalimat "mengarungi kehidupan pada masa dewasa", kalimat itu menegaskan bahwa pelayanan pendidikan di PAUD akan menjadi bekal mereka menjalani kehidupan sesuai dengan jamannya. Hal ini sesuai dengan perkataan sahabat Rasulullah yaitu Ali bin Abi Tholib untuk mendidik anak sesuai dengan jamannya.

Anak-anak yang berada pada jenjang anak usia dini akan menghadapi masa revolusi industri 4.0. Dunia pendidikan dimulai dari jenjang PAUD terkena imbas jaman revolusi industri 4.0. Revolusi industri yaitu jaman dimana teknologi berkembang sangat pesat hingga mempengaruhi sosial ekonomi dan budaya. Hal tersebut yang sedang terjadi pada masyarakat Indonesia, dimana kehidupan dalam kesehariannya tidak bisa lepas dari teknologi. Teknologi yang paling melekat pada anak usia dini saat ini adalah alat komunikasi berupa telepon genggam (handphone).

Dalam dunia pendidikan, di lembaga PAUD sudah banyak menggunakan alat teknologi sebagai media pembelajaran bahkan sebagai sumber belajar. Bruce Campbel dalam bukunya yang telah diterjemahkan "Metode Praktis Pembelajaran" menyatakan bahwa teknologi elektronik memiliki peran yang sanagt besar dalam perkembangan, 
PEDAGOGIKA

Volume 11 (Nomor 1) 2020

Hal. 1-11

khususnya perkembangan bahasa

(2006:34). Perkembangan bahasa yang

dimaksud yaitu kemamouan anak dalam berkomunikasi lisan maupun tulisan.

Begitu banyak hal yang dapat dipelari dari satu alat teknologi dimasa keemasan anak. Perkembangan ini tentu dirasakan untuk beberapa lembaga yang berada di perkotaan maupun di lembaga yang berada di pemukiman penduduk dengan perekonomian di atas rata-rata. Tetapi masih minim dirasakan untuk sebagian yang masih terbatas penyediaan alat teknologi dalam pembelajaran karena berkaitan dengan sumber dana. Sehingga belum adanya pemerataan dalam penggunaan variasi media dengan alat teknologi, seperti TV, Laptop, proyektor visual, komputer dan lainnya. Padahal saat ini sekolah dan lembaga pendidikan diwajibkan melakukan pelaporan melalui media internet.

Secara harfiah, pembelajaran berasal dari awalan dan akhiran pe-dan-an yang berarti"menciptakan atau membuat jadi” serta kata belajar yang artinya proses perubahan tingkah laku. Dengan demikian, secara harfiah pembelajaran berarti menjadikan atau membuat proses perubahan tingkah laku. Menurut (Hapidin, 2006) pembelajaran adalah usaha dari guru (pendidik) untuk menyampaikan, menciptakan, dan mengembangkan situasi 
PEDAGOGIKA

Volume 11 (Nomor 1) 2020

Hal. 1-11

Informasi diartikan oleh (Sutabri, 2014)

perkembangannya dalam lingkup suatu teknologi yang digunakan untuk pembelajarannya. Tidak hanya sebatas mengolah data, termasuk memproses, mendapatkan, menyusun, menyimpan, memanipulasi data dalam berbagai cara untuk menghasilkan informasi yang berkualitas, yaitu informasi yang relevan, akurat dan tepat waktu, yang digunakan keperluan pribadi, bisnis, dan pemerintahan dan merupakan informasi yang strategis untuk pengambilan keputusan.

Menurut (Jamal M.A., 2011) perangkat-perangkat teknologi informasi: 1) Komputer, 2) Laptop/Notebook, 3) Deskbook, 4) Personal Digital Assistant (PDA)/Komputer Genggam, 5) Flashdisk, CD, DVD, Disket, Memorycard. Aplikasi TI di dunia pendidikan antara lain sebagai perangkat lunak pengajaran, memberikan fasilitas untuk anak belajar mengambil keuntungan dari TI, belajar jarak jauh, informasi dan pengetahuan tentang pendidikan. Menurut (Davies, 1989), penggunaan perangkat lunak TI dalam proses pembelajaran akan meningkatkan efisiensi, meningkatkan motivasi, memberi fasilitas belajar aktif memfasilitasi belajar eksperimental, konsisten dengan belajar yang berpusat pada siswa dan memandu untuk belajar lebih baik.

$$
\text { Berdasarkan kebutuhan PAUD }
$$
tersebut, maka TK Bunga Bangsa memasukkan pengenalan teknologi dan media, tetapi pengetahuan perkembangan teknologi beserta keterampilan dalam menggunakan teknologi juga menjadi lingkup pembelajaran di TK Bunga Bangsa Islamic School Bekasi.

\section{METODE PENELITIAN}

Penelitian ini menggunakan metode penelitian deskriptif kualitiatif. Fokus masalah dalam penelitian ini yaitu implementasi dan strategi pembelajaran berbasis IT di TK Bunga Bangsa Islamic School Bekasi. Metode ini dipilih peneliti karena penelitian ini akan menggambarkan keunikan program pembelajaran di TK Bunga Bangsa Islamic School Bekasi secara jelas, terperinci dan akurat. Seperti pedapat (Nana Syaodih, 2006:72) yang menyatakan bahwa penelitian deskriptif adalah suatu bentuk penelitian yang ditujukan untuk mendeskripsikan fenomena-fenomena yang ada, baik fenomena alamiah maupun fenomena buatan manusia. Fenomena yang dimaksud dalam pendapat tersebut yaitu aktivitas, bentuk, perbedaan dan persamaan fenomena dan juga perubahan yang terjadi. Jenis penelitian deskriptif ini yaitu analisis dokumenter.

Menurut (Nana Syaodih, 2012) analisis dokumenter ini dilaksanakan untuk makna, kedudukan dan hubungan antara Pedagogika.fip@ung.ac.id P-ISSN : 2086-4469 E-ISSN : 2716-0580 


\section{PEDAGOGIKA}

Volume 11 (Nomor 1) 2020

Hal. 1-11

berbagai konsep, kebijakan, program, menggunakan model pembelajaran inovatif kegiatan, peristiwa yang ada atau yang berciri khas yang dinamakan NCM terjadi, untuk selanjutnya mengatahui manfaat, hasil atau dampak dari hal-hal tersebut. Dalam penelitian ini peneliti akan menganalisa dokumen kurikulum yang ada di TK Bunga Bangsa Islamic School Bekasi. Analisa dokumen ini akan dilihat dari berbagai hal seperti konsep pembelajaran PAUD, teori perkembangan untuk anak usia dini, kebijakan pemerintah dan dampak dari pelaksanaan kurikulum di TK Bunga Bangsa Islamic School Bekasi.

Penelitian ini dilakukan selama 3 bulan yaitu bulan September - November 2018. Pengumpulan data dilakukan dengan metode wawancara, observasi, dan analisa dokumen. Wawancara dilakukan kepada Kepala Sekolah, guru, anak didik dan juga orang tua. Data yang terkumpul akan dilakukan keabsahan data dengan triangulasi sumber dan juga teknik data. Triangulasi teknik data melalui penyajian data, reduksi data dan penarikan kesimpulan.

\section{HASIL PENELITIAN DAN}

\section{PEMBAHASAN}

Penelitian ini dilakukan di TK Bunga Bangsa Islamic School Bekasi. Lembaga ini di bawah Yayasan Masjid Jami Bunga Bangsa. TK Bunga Bangsa Islamic School berdiri sejak tahun 2012, sejak awal berdiri TK ini telah (Natural and Centre Model). Program pembelajarannnya pun disesuaikan dengan model pembelajaran yang menjadi konsep pembelajaran di TK Bunga Bangsa Islamic School. Kurikulum yang digunakan menggunakan referensi dari beberapa asosiasi internasional seperti NAEYC, DODEA dan juga kurikulum yang dikeluarkan pemerintah yaitu Kurikulum 2013. Berdasarkan dari hasil observasi, wawancara dan analisis dokumen maka didapat gambaran dan hasil penelitian berdasarkan fokus permasalahannya sebagai berikut:

\section{Implementasi pembelajaran berbasis IT} di TK Bunga Bangsa Islamic School.

TK Bunga Bangsa Islamic School Bekasi memiliki program pembelajaran yang diadaptasikan dari beberapa referensi program pembelajaran NAEYC, DoDEA dan juga kurikulum 2013 yang ada dalam Peraturan Pemerintah nomor 137 tahun 2014. Isi program pembelajaran tersebut terlihat dari standar tingkat pencapaian perkembangan yang ada di aspek perkembangan sosial dan juga sains, dimana isi standar tingkat pencapaian perkembangan itu diaplikasikan dalam program pembelajaran di sentra sosial studi dan sentra sains. Secara implisit setiap sentra akan memasukan perkembangan 
PEDAGOGIKA

Volume 11 (Nomor 1) 2020

Hal. 1-11

teknologi dalam setiap tema. Standar sains :

tingkat pencapaian perkembangan sentra

Tabel 1. Standar Tingkat Pencapaian Perkembangan Bidang Pengembangang Sains

\section{A. BIDANG PENGEMBANGAN SAINS}

\section{Ketermpilan inquiry}

(Inquiry Skill).
1 Melakukan kegiatan penelitian.

\section{KELOMPOK A}

1.1 Menjelaskan hasil pengamatan suatu objek.

1.3 Menjelaskan perbedaan 2 buah 1.4 Mendeskripsikan perbedaan 2 buah benda

\section{KELOMPOK B}

\section{Konsep Fisika (Physical \\ Science).}

1.5 Mengklasifikasi menurut cirinya (sifat)

2.1 Menjelaskan tekstur suatu 2.2 Mendeskripsikan tekstur suatu benda.

benda 1.6 Mengkategorikan benda menurut cirinya (sifat).

\begin{tabular}{|c|c|c|c|c|c|}
\hline $\begin{array}{l}\text { Mendeskripsikan } \\
\text { sifat dan kegunaan }\end{array}$ & 2.1 & $\begin{array}{l}\text { Menjelaskan } \\
\text { benda. }\end{array}$ & suatu & 2.2 & $\begin{array}{l}\text { Mendeskripsikan } \\
\text { benda. }\end{array}$ \\
\hline da. & 2.3 & $\begin{array}{l}\text { Menjelaskan kegunaan } \\
\text { benda. }\end{array}$ & suatu & 2.4 & $\begin{array}{l}\text { Menjelaskan kegunaan dan sifat } \\
\text { suatu benda. }\end{array}$ \\
\hline & 2.5 & $\begin{array}{l}\text { Menyebutkan sifat } \\
\text { secara sederhana. }\end{array}$ & net & 2.6 & $\begin{array}{l}\text { Menjelaskan daya tarik bumi } \\
\text { secara sederhana. }\end{array}$ \\
\hline
\end{tabular}

\section{Kecakapan Hidup (Life}

Skill).

\begin{tabular}{|c|c|c|c|c|c|}
\hline \multirow[t]{3}{*}{3.} & \multirow{3}{*}{$\begin{array}{l}\text { Mengidentifikasi } \\
\text { bagian tubuh, } \\
\text { kegunaan dan cara } \\
\text { perawatan. }\end{array}$} & 3.1 & Menjelaskan bagian - bagian & 3.2 & Mendeskripsikan bagian - bagian \\
\hline & & 3.3 & $\begin{array}{l}\text { Menjelaskan kegunaan bagian- } \\
\text { bagian tubuh mahluk hidup. }\end{array}$ & 3.4 & $\begin{array}{l}\text { Mendeskripsikan kegunaan bagian- } \\
\text { bagian tubuh mahluk hidup. }\end{array}$ \\
\hline & & 3.5 & $\begin{array}{l}\text { Menyebutkan cara merawat } \\
\text { tubuh }\end{array}$ & 3.6 & Menjelaskan cara merawat tubuh. \\
\hline \multirow[t]{5}{*}{4.} & \multirow{5}{*}{$\begin{array}{l}\text { Memberdayakan } \\
\text { lingkungan sekitar }\end{array}$} & 4.1 & Menjelaskan & 4.2 & Mendeskripsikan \\
\hline & & & an bersih dan kotor. & & $\mathrm{n}$ bersih dan kotor. \\
\hline & & 4.3 & $\begin{array}{l}\text { Menjelaskan mahluk hidup } \\
\text { yang ada di darat dan di air. }\end{array}$ & 4.4 & $\begin{array}{l}\text { Mendeskripsikan mahluk hidup } \\
\text { yang ada di darat dan di air. }\end{array}$ \\
\hline & & 4.5 & $\begin{array}{l}\text { Membedakan makhluk hidup } \\
\text { dan benda mati. }\end{array}$ & 4.6 & $\begin{array}{l}\text { Menjelaskan makhluk hidup dan } \\
\text { benda mati. }\end{array}$ \\
\hline & & 4.7 & $\begin{array}{l}\text { Menyebutkan cara menjaga } \\
\text { lingkungan sekitar. }\end{array}$ & 4.8 & $\begin{array}{l}\text { Menjelaskan cara } \\
\text { lingkungan sekitar. }\end{array}$ \\
\hline
\end{tabular}

\section{Bumi dan Luar}

angkasa.

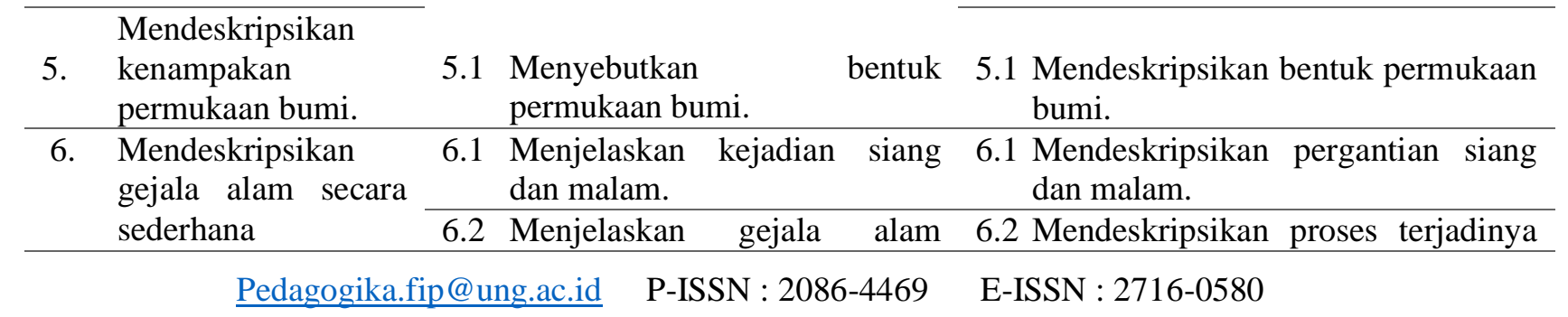


PEDAGOGIKA

Volume 11 (Nomor 1) 2020

Hal. 1-11

\begin{tabular}{|c|c|c|c|c|}
\hline & \multicolumn{2}{|r|}{ tentang turunnya hujan. } & hujan. \\
\hline & & 6.3 & Menjelaskan musim & 6.3 Mendeskripsikan pergantian musim \\
\hline \multirow[t]{2}{*}{7} & $\begin{array}{l}\text { Mendeskripsikan } \\
\text { benda - benda yang } \\
\text { ada di langit. }\end{array}$ & 7.1 & $\begin{array}{l}\text { Menjelaskan benda - benda } \\
\text { langit yang dapat dilihat pada } \\
\text { siang dan malam hari. }\end{array}$ & $\begin{array}{l}\text { 7.1 Mendeskripsikan benda - benda } \\
\text { langit yang dapat dilihat pada siang } \\
\text { dan malam hari. }\end{array}$ \\
\hline & & 7.2 & $\begin{array}{l}\text { Menyebutkan beberapa nama } \\
\text { planet. }\end{array}$ & 7.2 Menjelaskan beberapa nama planet. \\
\hline
\end{tabular}

\section{Hubungan sains dan} teknologi.
8. Mendeskripsikan
8.1 Menjelaskan
cara 8.1 Mendeskripsikan
cara
kegunaan dan
penggunaan menggunakan alat teknologi.
menggunakan alat teknologi.
teknologi dalam
8.2 Menjelaskan perubahan
8.2 Menjelaskan perubahan ukuran kehidupan sehari - ukuran benda apabila dilihat dengan kaca pembesar. benda apabila dilihat dengan kaca pembesar hari.

\section{Perspektif Sains.}

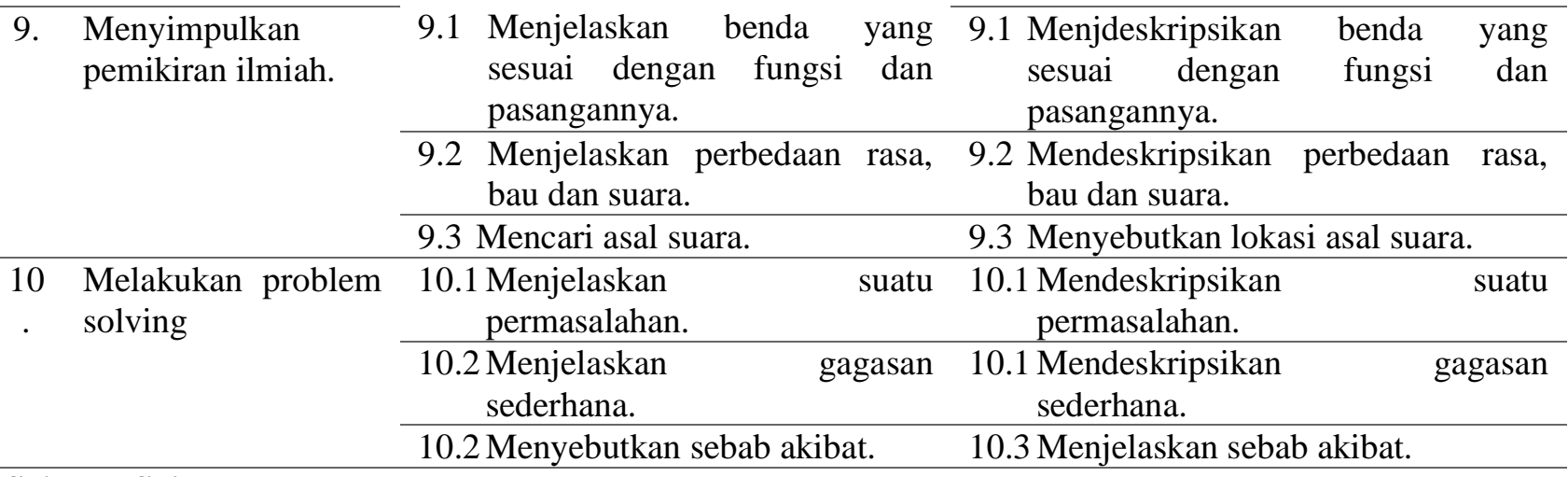

\section{Sejarah Sains.}

11 Mendeskripsikan asal mula sesuatu.

\subsection{Menjelaskan asal mula} sesuatu.

11.2 Menjelaskan metamorphosis 11.2 Mendeskripsikan metamorphosis hewan secara sederhana.

11.1 Mendeskripsikan asal mula
sesuatu.
$\begin{gathered}\text { 11.2 Mendeskripsikan metamorphosis } \\ \text { hewan secara sederhana }\end{gathered}$

Sumber: Dokumentasi TK Bunga Bangsa Islamic School

Berdasarkan standar pencapaian perkembangan yang dikembangkan oleh TK Bunga Bangsa Islamic School terlihat bahwa dalam perencanaan, proses dan output (kompetensi lulusan) memasukan pengetahuan dan keterampilan menggunakan teknologi dalam kehidupan sehari-hari. Hal tersebut di masukan khusus dalam aspek hubungan sains dan teknologi standar kompetensi nomor 8. Menurut wawancara dengan Kepala Sekolah ketika peneliti bertanya tentang proses perumusan kurikulum TK Bunga Bangsa, Kepala Sekolah menjelaskan proses merumuskan Standar Tingkat Pencapaian Perkembangan (STPP) yaitu selain menganalisis bebrapa referensi, Kepala Sekolah, guru dan Tim Kurikulum dari Yayasan juga Pedagogika.fip@ung.ac.id P-ISSN : 2086-4469 E-ISSN : 2716-0580 
PEDAGOGIKA

Volume 11 (Nomor 1) 2020

Hal. 1-11

mengobservasi kebutuhan dan tingkat pengenalan anak terhadap teknologi yang ada disekitar mereka.(CW.1)

Proses pelaksanaan pembelajaran yang selama ini berlangsung di sentra sains merupakan aktivtas yang sangat ditunggutunggu oleh anak-anak. Setiap sentra akan melakukan kegiatan dengan lima tahapan. Lima tahapan ini mencerminkan model pembelajaran alam (natural model). Lima langkah pembelajaran tersebut yaitu persiapan, pendahuluan, pengamatan, pembahasan, ekspresi. Proses pembelajaran yang diawalli dengan persiapan, dimana guru menyiapkan media dan sumber belajar yang dibutuhkan saat kegiatan. Setelah kegiatan klasikan di kelas maka anak-anak akan melanjutkan dengan aktivitas mooving class (berpindah dari satu sentra ke sentra yang lain sesuai dengan jadwal yang telah ditentukan). Aktivitas di sentra sains akan diawali dengan pendahuluan. Guru sentra sains akan memulai aktivitas dengan melakuan apersepsi, yaitu kegiatan yang dilakukan untuk menjembatani pengetahuan yang telah anak-anak dapatkan dengan materi baru yang akan dibahas. Kegiatan tersebut bisa dilakukan dengan tanya jawab, bercakap-cakap, diskusi dan juga bercerita. Kemudian kegiatan dilanjutkan dengan pengamatan, guru dan anak-anak bersama-sama mengamati media atau sumber belajar 
PEDAGOGIKA

Volume 11 (Nomor 1) 2020

Hal. 1-11

Kendala yang dialami dalam

implementasi pembelajaran berbasis IT di TK Bunga Bangsa Islamic School.

Berdasarkan hasil wawancara dengan 3 orang guru (Wali Kelas Kelompok B) mengenai kendala yang dialami oleh guru dalam melakukan proses pembelajaran menggunakan IT yaitu jika peralatan yang dibutuhkan terbatas jumlahnya. Keterbatasan jumlah sarana akan memerlukan kesabaran anak-anak dalam mengantri dalam menggunakannnya dan waktu yang lebih lama. Seperti dalam tema telekomunikasi, ketika akan membahas sub tema telepon genggam (handphone), jumlah telepon genggam yang bisa digunakan hanya tiga atau empat buah sedangkan ada 15 anak dalam satu kelas. (CW.3). Begitu juga dengan jumlah komputer yang tersedia 10 unit, sehingga ada anak yang menggunakan 1 unit komputer berdua.

Pada bagian keterampilan guru dalam menggunakan alat teknologi sebagai media dan juga sumber belajar, 2 dari 3orang guru menyatakan bahwa tidak ada kesulitan dalam menggunakan alat teknologi yang digunakan berupa TV, laptop dan projektor untuk menampilkan video, gambar atau suara dalam pembelajaran. Kendala guru dalam menggunakan alat teknologi yang ditemui

yaitu minimnya referensi sumber belajar yang sesuai dengan tema.

\section{Implementasi pembelajaran berbasis IT} di TK Bunga Bangsa Islamic School.

Pada bagian ini berisi temuan hasil penelitian tentaang implementasi pembelajaran berbasis TI di TK Bunga Bangsa Islamic School. Berdasarkan hasil pengumpulan data yang dilakukan peneliti melalui wawancara, observasi dan analisis dokumen maka terdapat tiga bagian penting dalam implementasi pembelajaran berbasis TI yaitu sarana, keterampilan guru dalam menggunakan IT dan pemilihan kegiatan yang sesuai tema.

Sarana yang dimiliki telah dioptimalkan dengan melengkapi barang-barang yang berbasis IT untuk media pembelajaran. Barang yang berbasis IT itu seperti laptop untuk setiap sentra, projektor di aula dan juga yang bisa dipakai di kelas, speaker, TV, tape, komputer dan beberapa alat teknologi yang disesuaikan dengan tema. Dilihat dari jumlah sarana yang digunakan untuk praktek langsung ke anak seperti komputer belum sejumlah anak, sehingga pelaksanaan pembelajaran dengan menggunakan komputer masih harus disiasati agar anak tidak bosan menunggu giliran atau memotivasi anak untuk mau bermain komputer bersama.

Keterpaduan media dan juga sumber belajar yang berbasis IT terlihat dari 
PEDAGOGIKA

Volume 11 (Nomor 1) 2020

Hal. 1-11

penyusunan perencanaan pembelajaran contoh RPPM :

yaitu RPPM dan RPPH. Berikut adalah

Tabel 2. Rencana Pelaksanaan Pembelajaran Mingguan Sentra Sains

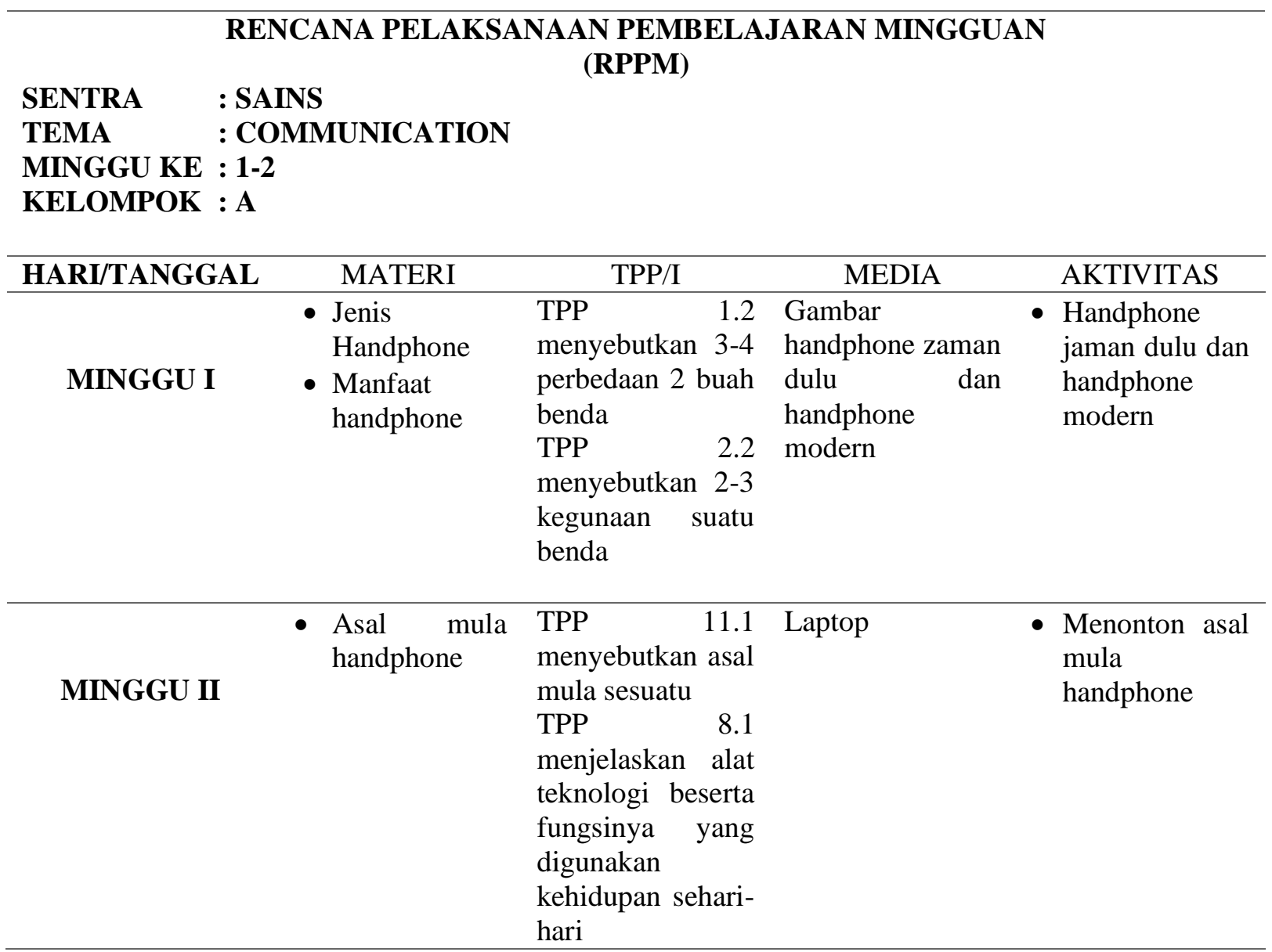

Dokumentasi RPPM TK Bunga Bangsa Islamic School

RPPM tersebut akan dideskripsikan

secara detail skenario pembelajarannya dalam RPPH. Tidak hanya terlihat di tema komunikasi yang memang menggunakan alat teknologi sebagai media alat teknologi dan juga sumber belajar. Pada tema lain seperti keluargaku, makanan dan minuman, tanaman, binatang, air, api, udara, transportasi, langit dan bumi selalu ada penggunaan media dan sumber belajar yang berbasis IT.

\section{KESIMPULAN}

Berdasarkan analisa implementasi pembelajaran berbasis TI di TK Bunga Bangsa Islmic School maka dapat terlihat adanya keterpaduan model pembelajaran, proses hingga standar kompetensi lulusan TK Bunga Bangsa Islamic School. Adapun kendala yang dihadapi oleh guru dapat diminimalisir dengan adanya diskusi dan berbagi pengetahuan serta pengalaman antar guru dalam menyajikan aktivitas yang berbasis IT. Hal itu menjadi keharusan bagi 
PEDAGOGIKA

Volume 11 (Nomor 1) 2020

Hal. 1-11

tim guru di TK Bunga Bangsa untuk dapat memberikan informasi dalam hal yang berkaitan dengan proses dan penilaian pembelajaran dikarenakan model pembelajaran yang digunakan yaitu model pembelajaran sentra. Hal ini sangat mendukung pemerataan pengetahuan dan keterampilan guru.Penggunaan TI dalam pembelajaran di KB \& TK Bunga Bangsa Islamic School telah menjadi satu kebutuhan guru ketika mengajar. Bukan hanya sekedar tempelan dalam indicator kurikulum saja. Penggunaan TI tidak hanya ketika penyampaian materi atau kegiatan dengan dengan anak-anak tetapi dimulai dari pembuatan perencanaan kegiatan pembelajaran, pelaksanaan proses pembelajaran hingga evaluasi dan pelaporan perkembangan. Fokus subjek penelitian ini lebih menekankan kepada keterampilan guru dalam menggunakan TI dalam proses pembelajaran, untuk itu penelitian selanjutnya yaitu akan melihat dampak penggunaan TI kepada hasil pembelajaran di PAUD dan keterampilan anak-anak dalam menggunakan TI dalam pembelajaran dan juga dalam kehidupan sehati-hari.

\section{REFERENSI}

Cambpbell, Linda, dan Campbell, Bruce dan Dickinson, Dee. 2006. Metode Praktis Pembelajaran Berbasis Multiple Intelligences. Depok: Isi Pres.
Davis, Fred D. 1989. "Perceived Usefulness, Perceived Ease of Use, and User Acceptance of Information Technology".September,pp.319-340. Tersedia:http://www.researchgate.net /publication/200085965.[17Agustus 2019].

Hapidin. 2006. Strategi Pembelajaran: Panduan Konseptual dan Praksis. Bekasi: Yayasan Pusdaini.

Kemendikbud.2017.http://referensi.data.ke mdikbud.go.id/index21.php

Ma'muAsmani, Jamal. 2011. Tips Efektif Pemanfaatan Teknologi Informasi Dan Komunikasi Dalam Dunia Pendidikan. Jogjakarta: Diva Press.

Mulyasa, E. 2003. Kurikulum Berbasis Kompetensi. Konsep, Karakteristik dan Implementasi. Bandung: Rosda Karya.

Nana Syaodih Sukmadinata 2000. Pengembangan Kurikulum, Teori dan Praktek. Bandung: Remaja Rosdakarya.

Permendikbud 2014 no.137. Standar Tingkat Pencapaian Perkembangan.

Syaodih, Nana. 2006. Landasan Psikologi Proses Pendidikan. Bandung: PT. Remaja Rosdakarya.

Tata Sutabri. 2014. Pengantar Teknologi Informasi. Yogyakarta: Andi

Tim Penyusun Naskah Akademik. 2013. Naskah Akademik TK Bunga Bangsa Islamic School. Bekasi. 